\title{
An Uplifted over Logistics Costs Efficiency by the Hub and Spoke System at Cikarang Dry Port
}

\author{
Nuh \\ Master of Management, Mercu Buana University \\ Jakarta, Indonesia
}

\begin{abstract}
This research aimed to discovered and analyzed those efficiency of logistics costs by hub and spoke system at Cikarang dry port that provides ports which included logistics services with logistics companies and supply chains so it would contributes to reducing logistics costs and dwelling time at Tanjung Priok Port. This research uses Factor Analysis and AHP (Analitycal Hierarchy Process) method as a method to find out all factors which influence most towards logistics performance and how to reduce those logistics costs at Cikarang Dry Port. Factor Analysis result starting from 14 elements into 8 elements which divided into 3 factors such as transportation, administration and inventory costs. The weight of loading and unloading costs is 0.24709 , the weight of container costs is 0.20384 and the weighting of stacking fees is 0.14429 . So AHP results was obtained from factors and elements of logistics costs Cikarang Dry Port which has most influence are F1 (loading and unloading costs), F6 (custom service fees), F8 (forwarding service costs), F2 (goods inspection service costs), F4 (stacking fees), F12 (service quality that needs to be improved), F3 (container tariffs), F5 (loading and unloading labor rates).
\end{abstract}

Keywords:- Analitycal Hirarki Process, Logistics Costs, Factor Analysis.

\section{INTRODUCTION}

Economic activities especially in world of trade which closely related to export and import activities are main activities in distribution of goods. The presence of industries in hinterland region encourages the creations of dry port concept that has functions like a seaport in general, and support to export, import and distribution of goods also commodities produced.

Dry Port is one of the logistics infrastructure, whereas dryport acts as a node in transportation network and supporter of economic activity. Cikarang Dry Port plays an important role of national connectivity by simplifying access between port and hinterland (for example an industrial area) as well as reducing traffic and congestion at Port of Tanjung Priok. CDP provides a port and logistics services which integrated with dozens of logistics companies and supply chains so it is expected to be able to reduce the density of loading and unloading currents and contribute to reducing dwelling time which will have an impact on reduction of container buildup at Tanjung Priok Port.

\author{
Sugeng Santoso \\ Lecturer of postgraduate, Mercu Buana University \\ Jakarta, Indonesia
}

Based on 2019 performance index logistic report, the waiting time at Tanjung Priok Port is still at 3-4 days, it is still inferior against Singapore which has very fast dwelling time movement with only 1 day.

\begin{tabular}{|c|c|c|}
\hline Country/Port & Dwell (in Day) 2019 & Remarks \\
\hline Singapore & 1 & Excellent/Fast \\
\hline Hongkong, China & 2 & Very Good/Fast \\
\hline Thailand & $2-3$ & Very Good/Fast \\
\hline Port Klang (Malaysia) & 3 & Good/Fair \\
\hline Tanjung Priok (INA) & $3-4$ & Good/Fair \\
\hline
\end{tabular}

Table 1:- Dwelling Time of Asean Countries

Source: Logistic Performance Index (2019)

By long waiting time often has results in shortages of goods, fluctuations and high disparity in prices of goods between regions. Beside that the high waiting time at Indonesia's logistics performance is seen to be low, which only has position 46 in 2018. The low performance of Indonesian logistics was influenced by low performance of logistics at PT. Cikarang Dry Port Indonesia.

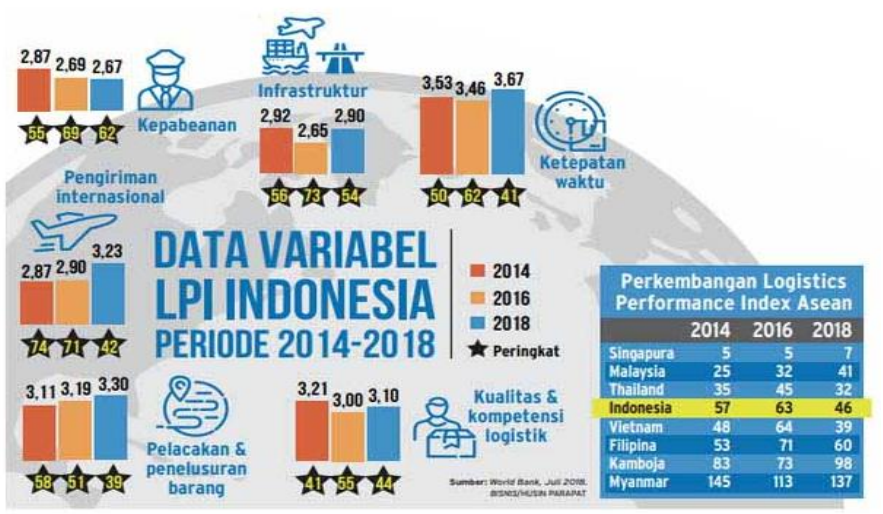

Fig 1:- The growth of Asean Logistics Performance Index Source Logistic Performance Index (2019)

The logistical performance assessment based on six aspects, such as efficiency of customs \& border management clearance (customs), the quality of trade and transportation infrastructure, an ease of international shipping arrangements, the competence and quality of logistics services, capabilities to do track \& tracing and frequency of timely deliveries. The Logistics Performance Index (LPI) also highlights over logistical costs in Indonesia, which still high at $23.5 \%$ in 2018. 


\begin{tabular}{|c|c|}
\hline Country & \% Logistics Costs to GDP \\
\hline Singapore & $8,1 \%$ \\
\hline Malaysia & $13,2 \%$ \\
\hline Thailand & $13,2 \%$ \\
\hline Vietnam & $15 \%$ \\
\hline Indonesia & $\mathbf{2 3 , 5} \%$ \\
\hline
\end{tabular}

Table 2:- Percentage of logistics costs to GDP of ASEAN countries

Source: Logistics Performance Index (2018)

The high cost of domestic logistics in Indonesia is not only caused by high cost of land and sea transportation but also due to other factors that related to regulations, human resources, logistics processes and management which still inefficient and lack of professionalism of national logistic service providers and resulting to inefficient domestic freight forwarding industry. Therefore, to reduce these problems and improve efficiency of logistic costs, a strategy to strengthen maritime logistics systems is needed to create a cheaper costs for logistics, one of way by applying concept of collectors and feeders (hub and spokes).

\section{THEORETICAL REVIEW}

\section{A. Logistics}

According to Li, X. in Karosekali and Santoso (2019) logistics is management of flow of goods movement start from original point and ends at point of consumption to meet certain demands. Whereas the understanding of logistics according to the Council of Supply Chain Management Professionals in Karosekali and Santoso (2019) logistics is part of supply chain management in planning, implementing and controlling the flow and storage of goods, information, and services which is effective and efficient from the original point to destination point according to consumer demand. Bowersox in Karosekali and Santoso (2019) said that there has 5 components which shaping logistic system, such as: structure facility location, transportation, inventory, communication and handling \& storage. With good logistics management it will be very effective to increase the company's marketing efforts by providing an efficient transfer of product to customers, time and place utility for the product. (Lambert and Stock in Karosekali and Santoso, 2019).

\section{B. Sizing of Logistics Performance}

According to Sorooshian and Yin (2013) SCM is network management of organizations from up to down which includes relations between two or more companies and flow of material both of information and resources. While logistics is a process of planning, implementing, and controlling procedures for transportation and storage of goods efficiently and effectively. Therefore its important to sizing up supply-logistics chain performance by apply it well through customer satisfaction surveys. Beside that, role of distribution network and its management is very important to meet consumer demand thereby increasing sales and profits. (Haryotejo, 2015).

\section{Crossdocking}

There are several types of crossdocking that can generally be applied, such as pre-packed cross docking, and intermediate handling cross docking. Meanwhile, in crossdocking warehouse management scenario it has 3 types, such as: manufactured cross docking, distributor cross docking and retail cross docking. (Abdillah in Karosekali and Santoso, 2019).

\section{Dry Port Concept}

According to Roso (2008) dry port concept is briefly characterized as an integrated transport terminal that located in some distance from seaport, connected to the seaport by road transportations such as, train or waterway and offers services available at sea ports, such as custom clearance, container maintenance, storage, forwarding, etc. He added that main purpose of dry port was to move activities from sea port to Dry Port to reduce congestion and achieve other benefits.

\section{E. Warehouse}

According to Rushton in Karosekali and Santoso(2019) stockroom or warehouse is an important component of modern supply chain. The supply chain involves activities in various stages such as sourcing, production and distribution of goods from handling raw materials and processed goods to finished products. Warehouse could be described as part of a company's logistics system that has functions to store products and provide information about status and condition of material or inventory stored in warehouse so the information will always up-to-date and easily accessible by anyone with an interest.

\section{F. Transportation}

According to Ritonga, et. al. (2015) Transportation is a process of movement of people or goods from one place to another by using certain system to meet human needs by moving and interacting. He further said that transportation costs are influenced by two factors, such as product-related factors to determine product classification for needs of manufacturing level and market-related factors to decide the level of competition, market location, applied regulations and balance of goods traffic in an area.

\section{G. Stock}

According to Stevenson W. J. \& Chuong S.C in Karosekali and Santoso(2019) inventory is stock or storage of goods. Inventories are not only necessary for operations but also contribute to customer satisfaction. Heizer and Render (2014) added that inventory has several functions, one of that is to eliminate risk of delays in delivery of raw materials or goods needed by the company, eliminate risk of availability of material which is not good so it should be returned, eliminate risk of seasonal price increases or inflation, and to store raw materials produced seasonally so the company won't have difficulties if the material is not available on the market. 


\section{H. Scheduling}

According to Stevenson W. J. \& Chuong S.C in Karosekali and Santoso(2019) said that scheduling related to timing of the specific use of resources of the organization. Scheduling mostly related to the use of equipment, facilities, and human activities. Scheduling occurs within each organization regardless of the nature of its activities. Effective schedule could get good result by savings costs and increased productivity.

\section{Factor Analysis}

According to Karosekali and Santoso(2019) factor analysis is an analysis used to reduce or summarize a number of variables to be fewer, but does not reduce the meaning of the original variables. Factor analysis aims to confirm the structure of factors analyzed based on the concept (theory) or measure the construct validity which shows how well the results that obtained from the use of meters accordance to theories. Another goal of factor analysis is to get a measure (in the form of a score) of latent variables based on several measurable variables. Based on the purpose of factor analysis, there are two types of factors analysis which is exploratory factor analysis and confirmatory factor analysis.

\section{J. Analytical Hierarchy Process (AHP)}

According to Saaty Karosekali and Santoso(2019) Analytical Hierarchy Process (AHP)is a method which seen details a complex or unstructured situation into components then organizes parts or variables of these components into a hierarchical arrangement and gives numerical value to this consideration to determine which variable has the highest priority. Furthermore, he added that AHP is useful to complex problems which not structured, do not have enough written data, such as problems: planning, discovering alternatives, prioritizing, selecting policies, source allocation, determining needs, forecasting results, system design, performance recognition and optimization in problem solving.

\section{K. Theoretical Framework} follows:

The framework for this research could be seen as

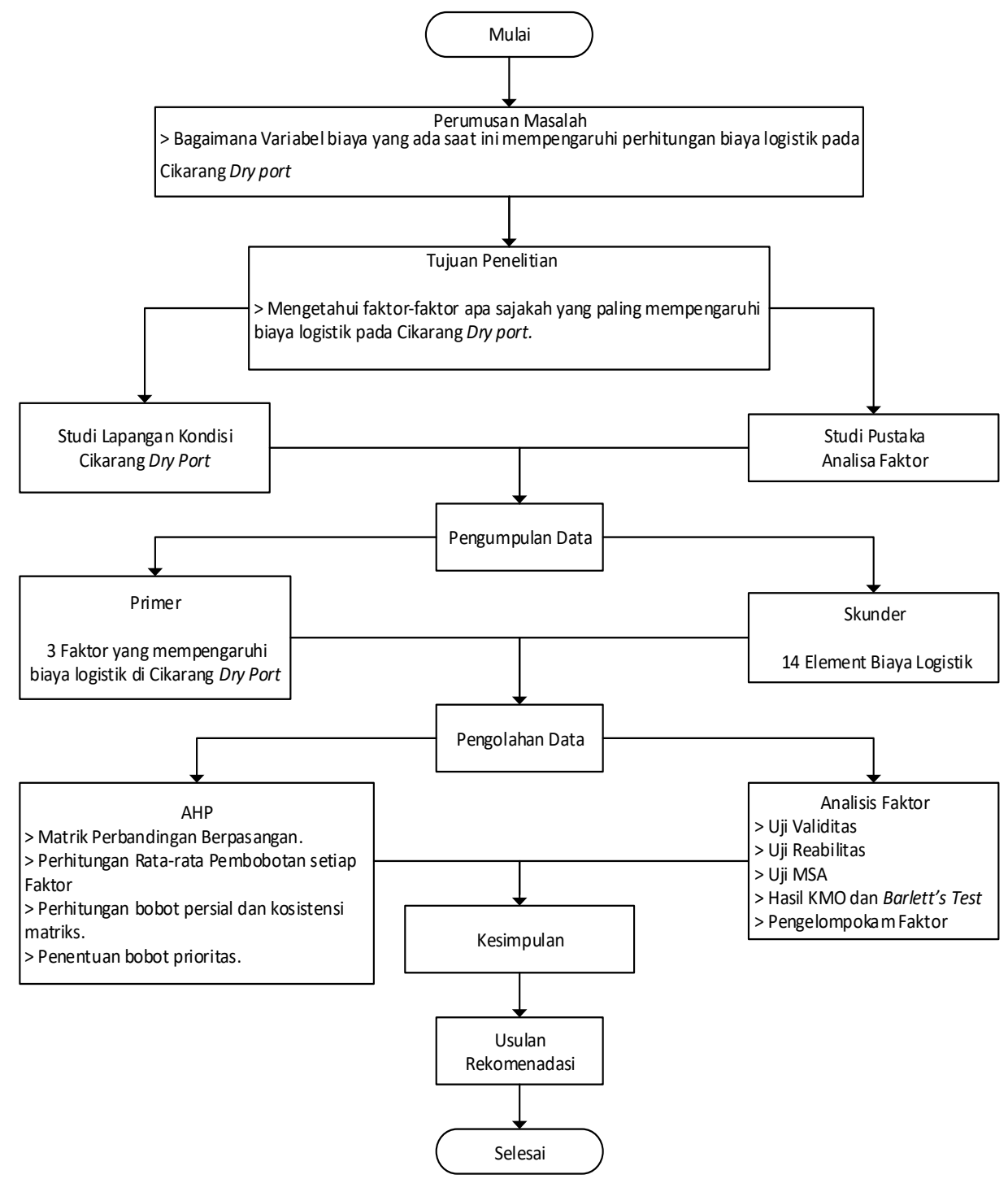

Fig 2:- Theoretical Framework 


\section{METHODOLOGY}

This type of research were conducted by quantitative research because in this research has several analyzes of numerical data. Among the statistical analyzes which carried out in the modeling stage of trip generation / pull of motion to determine the influence of socio variables of goods loading and unloading flows in Cikarang Dry Port. Based on research title, there has two types of variables that attributes in these research which is responsibility accounting $(\mathrm{X})$ and cost control (Y).

The population that used in this research was logistics service users priority lane, red lane, yellow lane and green lane as many as 120 companies who caught used logistics services in Cikarang Dry Port. The researchers took a sample of logistics service users from red line as many as 30 companies because its most expensive one than the others.

The data collection techniques used interviews that conducted in logistics section, especially domestic import section, direct and indirect observations on the field at domestic imports in Cikarang Dry Port and Cikarang Dry Port logistics service's users and questionnaires distributed to respondents.

In this research the authors used the Factor Analysis method which effective to reduce or summarize the number of elements to be fewer, but did not reduce the meaning of the original one. Beside that, the authors also use Analytical Hierarchy Process (AHP) method which could detailing complex or unstructured situation into components which arranged into hierarchical arrangement and provides numerical values in consideration to discovers which elements who has the highest priority.

\section{RESULT AND DISCUSSION}

\section{A. Validity and Reliability Test}

According to the results over validity test, it was found that entire value of $r$ results $>r$ table $(0.3610)$. This means that all statement items were declared valid. The results of validity test could be seen in Table 3 below.

\begin{tabular}{|c|c|c|}
\hline Variable & Correlation & Information \\
\hline F1 & 0.614 & Valid \\
\hline F2 & 0.489 & Valid \\
\hline F3 & 0.515 & Valid \\
\hline F4 & 0.404 & Valid \\
\hline F5 & 0.485 & Valid \\
\hline F6 & 0.674 & Valid \\
\hline F7 & 0.372 & Valid \\
\hline F8 & 0.442 & Valid \\
\hline F9 & 0.562 & Valid \\
\hline F10 & 0.483 & Valid \\
\hline F11 & 0.506 & Valid \\
\hline F12 & 0.379 & Valid \\
\hline F13 & 0.406 & Valid \\
\hline F14 & 0.486 & Valid \\
\hline
\end{tabular}

Table 3:- Validity Test Results

Then, the reliability test results showed from that Cronbach's Alfa result $0.861>0.60$. Then it could be defined that results of these measurement of variables were reliable to use in subsequent analyzes,such as factor analysis.

\begin{tabular}{c|c}
\hline Cronbach's Alpa & Nof Item \\
\hline 0.753 & 14 \\
\hline Table 4:- Reliability Test Results
\end{tabular}

\section{B. Measure of Sampling Adequacy (MSA)}

Measure of Sampling Adequacy (MSA) used to discover whether an element is sufficient for further analysis. This value could be seen from the anti-image correlation matrix value. The MSA estimation value which process was carried out four times until finally all variables have a MSA value $>0.5$, there are 8 variables that will be used for the next factor analysis process.

\begin{tabular}{|c|c|c|c|c|c|c|c|}
\hline \multicolumn{2}{|r|}{ First Calculation } & \multicolumn{2}{|r|}{ Second Calculation } & \multicolumn{2}{|r|}{ Third Calculation } & \multicolumn{2}{|r|}{ Fourth Calculation } \\
\hline Variable & Anti image correlation matrix & Variable & Anti image correlation matrix & Variable & Anti image correlation matrix & Variable & Anti image correlation matrix \\
\hline $\mathrm{F} 1$ & 0.557 & $\mathrm{~F} 1$ & 0.671 & $\mathrm{~F} 1$ & 0.648 & $\mathrm{~F} 1$ & 0.741 \\
\hline F3 & 0.602 & F3 & 0.595 & F3 & 0.615 & F3 & 0.631 \\
\hline F4 & 0.530 & F4 & 0.577 & F4 & 0.639 & F4 & 0.704 \\
\hline F5 & 0.663 & F5 & 0.565 & F5 & 0.615 & F5 & 0.623 \\
\hline F8 & 0.624 & F12 & 0.805 & F12 & 0.796 & F12 & 0.795 \\
\hline F9 & 0.431 & F13 & 0.430 & F14 & 0.453 & & \\
\hline F10 & 0.328 & F14 & 0.539 & & & & \\
\hline F11 & 0.487 & & & & & & \\
\hline $\mathrm{F} 12$ & 0.521 & & & & & & \\
\hline
\end{tabular}

Table 5:- Test Results of Measure of Sampling Adequacy (MSA) 
C. Kaiser Meyer-Olkin (KMO) Measure of Sampling Adequacy and Bartlett's Test of Sphericity

The Kaiser Meyer-Olkin Index (KMO) Measure of Sampling Adequacy and the Bartlett's Test of Sphericity significance value were used to examine those accuracy of use of factor analysis. From these results of tests that have been done, it can be seen that the KMO value is 0.665 or between $0.5-1$ and the significance value is $0.009<0.05$ so it could be interpreted that factor analysis is appropriately used.

\begin{tabular}{|c|c|}
\hline Kaiser-Meyer-Olkin Measure of Sampling Adequacy & 0,665 \\
\hline Bartlett's Tesr of Sphericity Approx. Chi-Square & 48,775 \\
\hline Df & 28 \\
\hline Sig & 0,009 \\
\hline
\end{tabular}

Table 6:- Results of KMO and Barlett's Test

\section{Shapping Factor}

After found those elements and selected and correlation estimation has been fulfilled as for requirements ,and next step is to creating a factor to determined the structure that underlies to the link between the initial variables. The method that used in shapping factor was the principal component analysis method. The two main steps in shapping the factors were determining the number of factors and rotating the factors formed. These results could be seen in Table 7 below.

\begin{tabular}{|l|r|r|r|r|r|r|}
\hline \multirow{2}{*}{ Component } & \multicolumn{3}{|c|}{ Initial Eigenvalues } & \multicolumn{2}{c|}{ Extraction Sums of Squared Loadings } \\
\cline { 2 - 7 } & Total & \% of Variance & Cumulative \% & Total & \% of Variance & Cumulative \% \\
\hline 1 & 2.788 & 34.845 & 34.845 & 2.788 & 34.845 & 34.845 \\
2 & 1.425 & 17.815 & 52.660 & 1.425 & 17.815 & 52.660 \\
3 & 1.134 & 14.169 & 66.829 & 1.134 & 14.169 & 66.829 \\
4 & .751 & 9.391 & 76.220 & & & \\
5 & .674 & 8.424 & 84.644 & & & \\
6 & .527 & 6.586 & 91.230 & & & \\
7 & .363 & 4.532 & 95.762 & & & \\
8 & .339 & 4.238 & 100.000 & & & \\
\hline
\end{tabular}

Extraction Method: Principal Component Analysis.

Table 7:- Total Variance Explained

The first criteria used is the eigenvalue, from the table above, an eigenvalue greater than 1 in factors 1,2 and 3 is obtained. With this criterion, the number of factors used is 3 factors. The second criterion is the determination based on the percentage value of total variance that can be explained by the number of factors to be formed. From the table above, interpretation can be made relating to the cumulative total variance of the sample. If the elements are summarized into several factors, then the total value of variance that can be explained is as follows:

$>$ If all 8 elements are extracted into 1 factor, the total variance that can be explained is $2.788 / 8 \times 100 \%=$ $34.845 \%$.

$>$ If the 8 elements are extracted into 2 factors, the total variance that can be explained is $1.425 / 8 \times 100 \%=$ $17.815 \%$, and the cumulative total variance for the 2 factors is $34.845 \%+17.815 \%=52.660 \%$

$>$ If all 8 elements are extracted into 3 factors, the total variance that can be explained is $1.134 / 8 \times 100 \%=$ $14.169 \%$, and the cumulative total variance for the 3 factors is $34.845 \%+17.815 \%+14.169 \%=66.829 \%$

Thus the extraction of 3 factors obtained can be stopped and has met the second criterion. The third criterion is the determination based on the scree plot, from the results of the scree plot test it is known that the scree plot begins to level off at the extraction of the initial elements into 3 factors. From the combination based on these three criteria, it could be said that the most appropriate factor extraction is 3 factors.

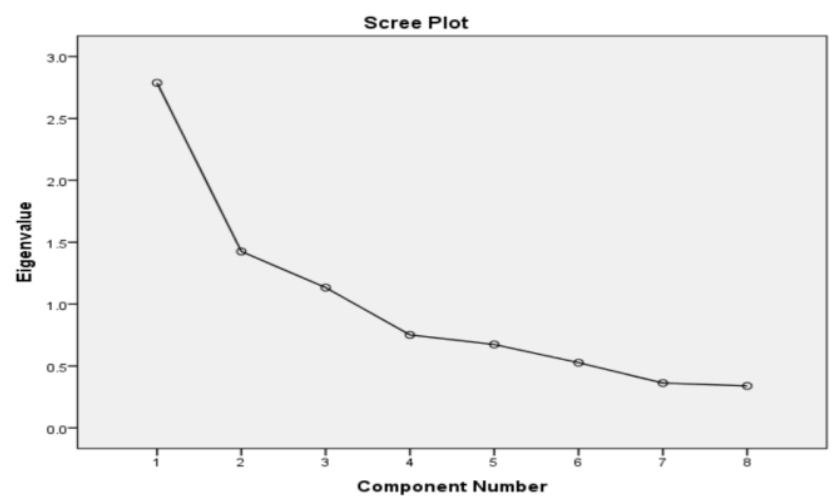

Fig 3:- Scee Plot

\section{E. Community}

Communality is basically the amount of variance of a variable that can be explained by existing factors. Based on the results of the community test, it is known that extraction values for all variables are $>0.50$. Thus, it can be concluded that all variables can be used to explain factors. 


\begin{tabular}{|c|c|c|c|c|c|c|c|c|}
\hline & $\mathrm{F} 1$ & $\mathrm{~F} 2$ & $\mathrm{~F} 3$ & $\mathrm{~F} 4$ & $\mathrm{~F} 5$ & $\mathrm{~F} 6$ & $\mathrm{~F} 8$ & $\mathrm{~F} 12$ \\
\hline Initial & 1.000 & 1.000 & 1.000 & 1.000 & 1.000 & 1.000 & 1.000 & 1.000 \\
\hline Extraction & 0,589 & 0,772 & 0,8 & 0,607 & 0,775 & 0,55 & 0,653 & 0,6 \\
\hline
\end{tabular}

Table 8:- Communality Test

\section{F. Component Matrix}

After knowing that the 3 factors are the most optimal number, the matrix component table shows the distribution of the 8 elements on the 3 factors formed while the figures in the table are factor loadings, which shows the correlation between an element and factor 1 factor 2 and factor 3 . The process of determining which elements will be included into which factors, carried out by making a large comparison of the correlation of each row.

\begin{tabular}{|c|c|c|c|c|c|c|c|c|}
\hline Factor & F1 & F2 & F3 & F4 & F5 & F6 & F8 & F12 \\
\hline 1 & 0,576 & 0,449 & 0,624 & 0,672 & 0,618 & 0,733 & 0,498 & 0,496 \\
\hline 2 & $-0,506$ & 0,735 & 0,346 & 0,339 & $-0,234$ & $-0,066$ & $-0,579$ & 0 \\
\hline 3 & $-0,022$ & 0,177 & $-0,539$ & 0,201 & $-0,582$ & 0,094 & 0,264 & 0,595 \\
\hline
\end{tabular}

Table 9:- Component Matrix

\section{G. Rotation}

The process of rotation in the results of this study aims to obtain factors with loading factors that are clear enough for interpretation. The results obtained indicate that the loading factor values between an element and several factors are sufficiently differentiated and ready to be interpreted. All elements have a high loading factor on one factor and have a loading factor that is small enough for other factors.

\begin{tabular}{|c|c|c|c|c|c|c|c|c|}
\hline Factor & F1 & F2 & F3 & F4 & F5 & F6 & F8 & F12 \\
\hline 1 & 0,708 & $-0,21$ & $-0,056$ & 0,221 & 0,35 & 0,518 & 0,808 & 0,492 \\
\hline 2 & $-0,009$ & 0,843 & 0,381 & 0,718 & $-0,035$ & 0,433 & 0,016 & 0,548 \\
\hline 3 & 0,297 & 0,131 & 0,807 & 0,207 & 0,807 & 0,307 & 0,009 & $-0,239$ \\
\hline
\end{tabular}

Table 10:- Rotated Component Matrix

\section{H. Interpretation of Factor Analysis Results.}

Based on Table 10 it appears that the F1 element has the highest loading factor value at factor 1 which is 0.708 . According to the guidelines previously mentioned, the value has been considered significant because it is greater than 0.50 . While the loading factor value of F1 elements in factors 2 and 3 is very small, so this element is included in factor 1. Element F2 has the highest loading factor value in factor 2, 0.843. According to the guidelines above, the value has been considered significant because it is greater than 0.50 . While the loading factor value by factors 1 and 3 is very small, so this element is included in factor 2 . Likewise, the determination of the other elements in factor 3. The following is Table 11 shows the results of grouping elements into factors.

\begin{tabular}{|c|c|}
\hline Factor & Element \\
\hline Transportation & F1, F6, F8 \\
\hline Administration & F2, F4, F12 \\
\hline Stock & F3, F5 \\
\hline
\end{tabular}

Table 11:- Results of Grouping and Naming Elements into Factors

\section{Logistics Cost Evaluation by Hierarchy Structure at PT. Cikarang Dry Port}

Hierarchical structure used to find out cost factors that most influence to logistics costs at PT. Cikarang Dry Port on current. The costs was obtained by grouping by factor analysis in previous stage then arranged into hierarchical form as can be seen in Figure 4 below.

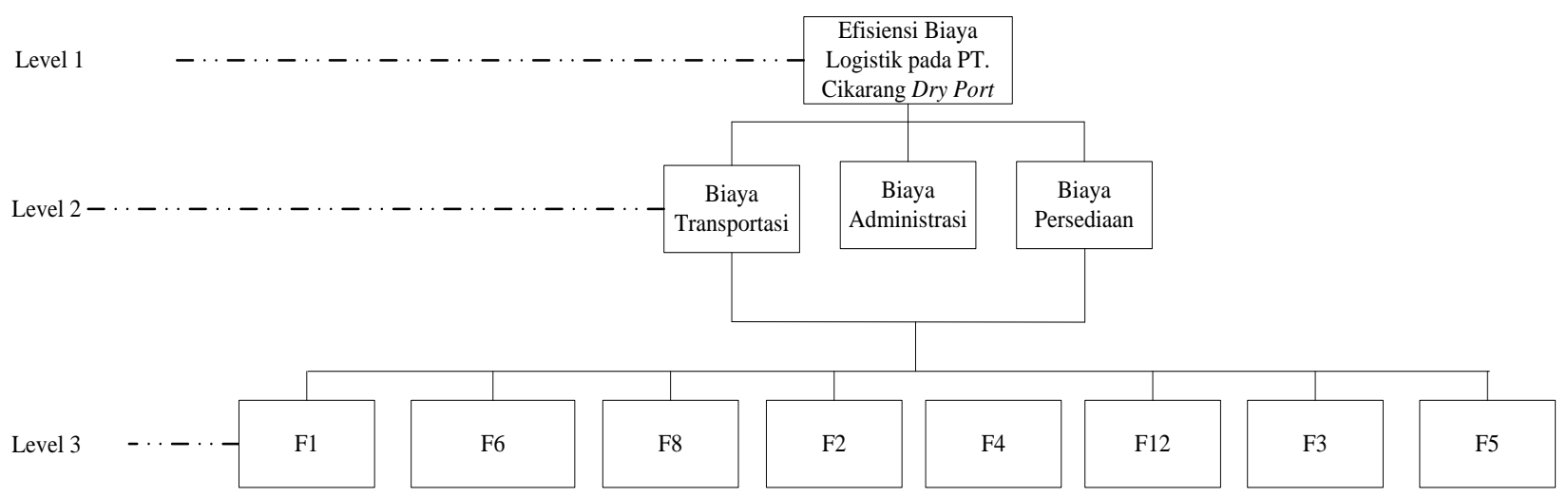

Fig 4:- Logistics Cost Efficiency Hierarchy Structure at Cikarang Dry Port 
J. Pairwise Comparison Matrix

Paired comparison matrix at level 2 were obtained from the results of a questionnaire that is part of the AHP.
This matrix aimed to see the comparison of each cost and level of important of each cost.

\begin{tabular}{|c|c|c|c|}
\hline \multirow{2}{*}{ Element } & \multicolumn{3}{|c|}{ Respondent 1} \\
\hline & Transportation & Administration & Stock \\
\hline Transportation & 1 & 3 & 5 \\
\hline Administration & $1 / 3$ & 1 & 3 \\
\hline Stock & $1 / 5$ & $1 / 3$ & 1 \\
\hline \multirow{2}{*}{ Element } & \multicolumn{3}{|c|}{ Respondent 2} \\
\hline & Transportation & Administration & Stock \\
\hline Transportation & 1 & $1 / 3$ & 5 \\
\hline Administration & 3 & 1 & 5 \\
\hline Stock & $1 / 5$ & $1 / 5$ & 1 \\
\hline \multirow{2}{*}{ Element } & \multicolumn{3}{|c|}{ Respondent 3} \\
\hline & Transportation & Administration & Stock \\
\hline Transportation & 1 & 3 & 5 \\
\hline Administration & $1 / 3$ & 1 & 5 \\
\hline Stock & $1 / 5$ & $1 / 5$ & 1 \\
\hline
\end{tabular}

Table 12:- Pairwise Comparison Matrix level 2

Pairwise comparison matrix at level 3 were obtained results of questionnaire that is part of the AHP. This matrix aims to see the comparison of each of the factors of each cost and the level of important of each of these factors.

\begin{tabular}{|c|c|c|c|c|c|c|c|c|}
\hline \multirow{2}{*}{ Element } & \multicolumn{8}{|c|}{ Respondent 1} \\
\hline & F1 & F6 & F8 & $\mathrm{F} 2$ & F4 & F12 & F3 & F5 \\
\hline $\mathrm{F} 1$ & 1 & 3 & 7 & 5 & $1 / 3$ & 9 & 3 & 3 \\
\hline F6 & $1 / 3$ & 1 & 3 & 3 & $1 / 5$ & 5 & $1 / 3$ & 5 \\
\hline F8 & $1 / 7$ & $1 / 3$ & 1 & $1 / 3$ & $1 / 5$ & 3 & $1 / 5$ & 3 \\
\hline $\mathrm{F} 2$ & $1 / 5$ & $1 / 3$ & 3 & 1 & $1 / 2$ & 3 & $1 / 3$ & 5 \\
\hline $\mathrm{F} 4$ & 3 & 5 & 5 & 2 & 1 & 9 & 3 & 3 \\
\hline F12 & $1 / 9$ & $1 / 5$ & $1 / 3$ & $1 / 3$ & $1 / 9$ & 1 & $1 / 9$ & $1 / 5$ \\
\hline F3 & $1 / 3$ & 3 & 5 & 3 & $1 / 3$ & 9 & 1 & 3 \\
\hline F5 & $1 / 3$ & $1 / 5$ & 3 & $1 / 5$ & $1 / 3$ & 5 & $1 / 3$ & 1 \\
\hline \multirow{2}{*}{ Element } & \multicolumn{8}{|c|}{ Respondent 2} \\
\hline & $\mathrm{F} 1$ & F6 & F8 & $\mathrm{F} 2$ & $\mathrm{~F} 4$ & F12 & F3 & F5 \\
\hline F1 & 1 & 3 & 9 & 3 & 7 & 9 & $1 / 3$ & 5 \\
\hline F6 & $1 / 3$ & 1 & 5 & 3 & $1 / 2$ & 9 & $1 / 3$ & 3 \\
\hline F8 & $1 / 7$ & $1 / 5$ & 1 & $1 / 3$ & $1 / 3$ & 3 & $1 / 7$ & $1 / 5$ \\
\hline $\mathrm{F} 2$ & $1 / 3$ & $1 / 3$ & 3 & 1 & $1 / 3$ & 7 & $1 / 3$ & 3 \\
\hline $\mathrm{F} 4$ & $1 / 7$ & 2 & 3 & 3 & 1 & 9 & $1 / 5$ & $1 / 3$ \\
\hline F12 & $1 / 9$ & $1 / 9$ & $1 / 3$ & $1 / 7$ & $1 / 9$ & 1 & $1 / 9$ & $1 / 3$ \\
\hline F3 & 3 & 3 & 7 & 3 & 5 & 9 & 1 & 3 \\
\hline F5 & $1 / 9$ & $1 / 3$ & 5 & $1 / 7$ & 3 & 3 & $1 / 3$ & 1 \\
\hline \multirow{2}{*}{ Element } & \multicolumn{8}{|c|}{ Respondent 3} \\
\hline & $\mathrm{F} 1$ & F6 & $\mathrm{F} 8$ & $\mathrm{~F} 2$ & $\mathrm{~F} 4$ & F12 & F3 & F5 \\
\hline $\mathrm{F} 1$ & 1 & 3 & 9 & 3 & 5 & 9 & 3 & 5 \\
\hline F6 & $1 / 3$ & 1 & 4 & $1 / 3$ & 5 & 7 & $1 / 3$ & 3 \\
\hline F8 & $1 / 9$ & $1 / 4$ & 1 & $1 / 3$ & $1 / 3$ & 3 & $1 / 3$ & $1 / 5$ \\
\hline $\mathrm{F} 2$ & $1 / 3$ & 3 & 3 & 1 & $1 / 3$ & 5 & $1 / 3$ & 3 \\
\hline F4 & $1 / 5$ & $1 / 5$ & 3 & 3 & 1 & 5 & $1 / 3$ & $1 / 3$ \\
\hline F12 & $1 / 9$ & $1 / 7$ & $1 / 3$ & $1 / 5$ & $1 / 5$ & 1 & $1 / 9$ & $1 / 5$ \\
\hline F3 & $1 / 3$ & 3 & 3 & 3 & 3 & 9 & 1 & 3 \\
\hline F5 & $1 / 5$ & $1 / 3$ & 5 & $1 / 3$ & 3 & 5 & $1 / 3$ & 1 \\
\hline
\end{tabular}

Table 13:- Pairwise Comparison Matrix Level 3 
K. The Estimation of Average weight for Each Cost and Variables Costs

In AHP, weighting average estimation was done by using geometric averages. The geometric values is considered as the results of group assessments of the values given by respondents. The following results calculate the average weighting for costs.

\begin{tabular}{|c|c|c|c|}
\hline & Transportation & Administration & Stock \\
\hline Transportation & 1.000 & 1.442 & 5.000 \\
\hline Administration & 0.693 & 1.000 & 4.217 \\
\hline Stock & 0.200 & 0.237 & 1.000 \\
\hline
\end{tabular}

Table 14:- Estimation of Average Weighting for Costs

The calculation for weighting average of each cost factor has done by using the same method as the weighting calculation for criteria.

\begin{tabular}{|c|c|c|c|c|c|c|c|c|}
\hline & F1 & F6 & F8 & F2 & F4 & F12 & F3 & F5 \\
\hline F1 & 1.000 & 3.000 & 8.277 & 3.557 & 2.268 & 9.000 & 1.442 & 1.000 \\
\hline F6 & 0.333 & 1.000 & 3.915 & 1.442 & 0.794 & 6.804 & 0.333 & 0.333 \\
\hline F8 & 0.131 & 0.255 & 1.000 & 0.333 & 0.281 & 3.000 & 0.212 & 0.131 \\
\hline F2 & 0.281 & 0.693 & 3.000 & 1.000 & 0.382 & 4.718 & 0.333 & 0.281 \\
\hline F4 & 0.441 & 1.260 & 3.557 & 2.621 & 1.000 & 7.399 & 0.585 & 0.441 \\
\hline F12 & 0.111 & 0.147 & 0.333 & 0.212 & 0.135 & 1.000 & 0.111 & 0.111 \\
\hline F3 & 0.693 & 3.000 & 4.718 & 3.000 & 1.710 & 9.000 & 1.000 & 0.693 \\
\hline F5 & 0.195 & 0.281 & 4.217 & 0.212 & 1.442 & 4.217 & 0.333 & 0.195 \\
\hline
\end{tabular}

Table 15:- The Calculation of Average weighting for Variable Costs

\section{The Estimates of Partial weighting and Matrix} Consistency for Elements Level (Cost)

Before calculating the partial value and consistency matrix, there has an initial step that should be carried out, such as finding the average number of quality for each criteria. Those Calculation of the average value for criteria of transportation, administration and inventory costs could be seen as follows.

\begin{tabular}{|c|c|}
\hline Element & Amount \\
\hline Transportation & 1,893 \\
\hline Administration & 2,679 \\
\hline Stock & 10.217 \\
\hline
\end{tabular}

Table 16:- Sum of Average weighting for Elements Level 2

Next, the value on each cell was divided by sum of the results in each column. The results often called normalization matrix where the sum of numbers contained in each column will produce 1 .

\begin{tabular}{|c|c|c|c|c|}
\hline & Transportation & Administration & Stock & Partial Weight \\
\hline Transportation & 0.5282 & 0.5383 & 0.4894 & 0.5186 \\
\hline Administration & 0.3662 & 0.3732 & 0.4128 & 0.3841 \\
\hline Stock & 0.1056 & 0.0885 & 0.0979 & 0.0973 \\
\hline Total & 1.0000 & 1.0000 & 1.0000 & 1.0000 \\
\hline
\end{tabular}

Table 17:- Normalization Matrix and weighting of Each Element Line at Level 2

M. The Calculation of Partial weighting and Matrix Consistency for Elements Level 3 (Cost Variables)

Before doing partial weight calculations and matrix consistency, there are some initial steps which should be done. For example The first thing to do is find the average number of weights for each criteria. Calculation of the average number of weights for F1, F6, F8, F2, F4, F12, F3, and F5.

\begin{tabular}{|c|c|}
\hline Element & Total \\
\hline F1 & 3,1862 \\
\hline F6 & 9,6368 \\
\hline F8 & 290.167 \\
\hline F2 & 123.772 \\
\hline F4 & 8,0118 \\
\hline F12 & 45,1376 \\
\hline F3 & 4,3501 \\
\hline F5 & 16,7547 \\
\hline
\end{tabular}

Table 18:- Sum of Average Weightings for Each Elements Level 3 
Next, the value in each cell was divided by the sum of results in each column. Which called the normalization matrix where the sum of numbers every each column will produce 1.

\begin{tabular}{|c|c|c|c|c|c|c|c|c|c|}
\hline & F1 & F6 & F8 & F2 & F4 & F12 & F3 & F5 & Partial Weight \\
\hline F1 & 0.3139 & 0.3113 & 0.2852 & 0.2874 & 0.2831 & 0.1994 & 0.3315 & 0.2517 & 0.283 \\
\hline F6 & 0.1046 & 0.1038 & 0.1349 & 0.1165 & 0.0991 & 0.1507 & 0.0766 & 0.2123 & 0.125 \\
\hline F8 & 0.0412 & 0.0265 & 0.0345 & 0.0269 & 0.0351 & 0.0665 & 0.0487 & 0.0294 & 0.039 \\
\hline F2 & 0.0882 & 0.0719 & 0.1034 & 0.0808 & 0.0476 & 0.1045 & 0.0766 & 0.2123 & 0.098 \\
\hline F4 & 0.1384 & 0.1307 & 0.1226 & 0.2117 & 0.1248 & 0.1639 & 0.1344 & 0.0414 & 0.133 \\
\hline F12 & 0.0349 & 0.0153 & 0.0115 & 0.0171 & 0.0169 & 0.0222 & 0.0255 & 0.0142 & 0.020 \\
\hline F3 & 0.2176 & 0.3113 & 0.1626 & 0.2424 & 0.2134 & 0.1994 & 0.2299 & 0.1791 & 0.219 \\
\hline F5 & 0.0612 & 0.0292 & 0.1453 & 0.0171 & 0.1800 & 0.0934 & 0.0766 & 0.0597 & 0.083 \\
\hline Total & 1.0000 & 1.0000 & 1.0000 & 1.0000 & 1.0000 & 1.0000 & 1.0000 & 1.0000 & 1.0000 \\
\hline
\end{tabular}

Table 19:- Normalization Matrix and Weighting of Each Element's Line at Level 3

\section{N. Determination of Priority Weighting}

After obtained values from geometric mean, the partial weighting and consistency of the matrix which is the output of the AHP step will be sought. To get the priority list, the researchers used Super Decisions software . With initial step taken from this software to build the AHP hierarchy. Then the hierarchy and connection between levels in hierarchy were found out and the matrix of geometric averages that have been obtained in previous manual calculation will be input to the software aswell. After all geometric averages were input then the priority results would be obtained from the research by AHP method which seen as in Table 20.

\begin{tabular}{|c|c|}
\hline Element & Priority value (weighting) \\
\hline Loading and Unloading Costs (F1) & 0,24709 \\
\hline Customer Service Fee (F6) & 0,13984 \\
\hline Forwarding Services Rates (F8) & 0,03943 \\
\hline Goods Inspection Fee (F2) & 0,10932 \\
\hline Stacking Fee (F4) & 0,14429 \\
\hline Quality of Service that needs to be improved (F12) & 0,02159 \\
\hline Container Fee (F3) & 0,20384 \\
\hline TKBM Service Fares (F5) & 0,09461 \\
\hline
\end{tabular}

Table 20:- AHP Priority Weighting

From Table 20, it can be seen that 3 cost elements with highest contained and evaluation materials on logistics costs at PT. Cikarang Dry Port are elements of Loading and Unloading Costs (F1), Container Costs (F3), and Stacking Fee Rates (F4). As for the biggest cost factor contained is the quantity of Transportation Cost Factor which is equal to the Cost of Loading and Unloading Goods (F1) + Customes Service Fee $(\mathrm{F} 6)+$ Forwarding Services Tariff $(\mathrm{F} 8)=$ $0.24709+0.13984+0.03943=0.42636(42.63 \%)$, followed by the Inventory Cost Factor for the Container Fee $(\mathrm{F} 3)+$ TKBM Services Tariff $(\mathrm{F} 5)=0.20384+$ $0.09461=0.29845(29.84 \%)$ and finally the Factor Administrative costs of Goods Inspection Fee (F2) + Stacking Fee (F4) + Service Quality that needs to be improved $(\mathrm{F} 12)=0.10932+0.14429+0.02159=0.2752$ $(27.52 \%)$.

\section{CONCLUSION AND SUGGESTION}

\section{A. Conclusion}

Based on these results that have been described above, therefore several conclusions which could be drawn from this research are as in follows:

$>$ The results of the factor analysis which started from 14 cost elements into 8 cost elements and were divided into
3 factors, which is transportation costs, administrative costs and inventory costs.

> The results from AHP and obtained the most important cost which is transportation costs, when viewed from the total priority weighting owned is 0.42636 consisting of loading and unloading costs (F1), custom service costs (F6) and forwarding service costs (F8).

\section{B. Suggestion}

Based on the results that has been described above, as for suggestions the authors could drawn several recommendation such as:

$>$ The establishment of several new regulations and policies related to logistics cost elements at PT. Cikarang Dry Port which has most impact over the efficiency of logistics costs so it could be reduce logistics costs at PT. Cikarang Dry Port.

$>$ Find out and Add another cost elements for logistics at PT. Cikarang Dry Port which not include in cost elements that carried out in this research.

$>$ Try to discovered and compare this research by using other decision support methods such as ANP, Topsis, and others. 


\section{REFERENCES}

[1]. Haryotejo, Bimo. (2015). Analisis Pengaruh Kinerja Logistik Pemasok terhadap Kinerja Bisnis (Studi pada Bengkel AHASS di Kota Semarang). Semarang: Fakultas Ekonomika dan Bisnis Universitas Diponegoro.

[2]. Karosekali, Agus Fernando dan Sugeng Santoso. (2019) Analysis of Logistics Cost of The Maritime (Case of Tanjung Priok Port). International Journal of Innovative Science and Research Technology, 4(9):250-261.

[3]. Heizer. J., \& Render. B (2014).Operation Management. Eleventh Edition. USA: Pearson Education Limited.

[4]. Ritonga, D., Timboeleng, J.A., dan Kaseke, O.H., (2015). Analisa Biaya Transportasi Angkutan Umum dalam Kota Manado Akibat Kemacetan Lalu Lintas Studi Kasus: Angkutan Umum Trayek Pusat Kota 45Malalayang. Jurnal Sipil Statik, 3(1): 58-67.

[5]. Roso, Violeta. (2008) Emergence and Significance of Dry Ports. Division of Logistics and Transportation, Chalmers University of Technology, Sweden.

[6]. Sorooshian, S. dan Yin, D.T. (2013). Logistics Evaluation: a Case Study. International Journal of Engineering \& Technology Sciences, 1(4):192- 199. 